\title{
BIBLIOGRAFIA RUSSA SÔBRE O BARÃO JORGE HENRIQUE LANGSDORF.
}

Encontramos no livro Descobertas Russas na Antártica em 1819-1820-1821 (1) a seguinte nota a respeito da visita que os membros da expedição Belinghausen fizeram em 1819 ao conhecido cientista Langsdorf que, nessa época, era cônsul da Rússia no Rio de Janeiro Janeiro (2).

"Jorge Henrique Langsdorf, um notável explorador (17741852), nascido na Alemanha, passou a maior parte de sua vida ao serviço da Rússia. Tomou parte na primeira expedição russa em volta do mundo - dirigida por J. F. Krusenstiern - no navio $\mathrm{Na}$ dejda (Esperança) em 1803-1806. Viajou com Resanov para o Japão e para a América Russa. De volta a Petersburgo, foi nomeado membro-adjunto e mais tarde membro da Academia de Ciências. Em 1812, tornou-se cônsul da Rússia no Brasil.

Em 1831, Langsdorf fêz uma viagem a Petersburgo e conseguiu que os dirigentes da Academia organizassem uma expedição ao interior do Brasil, então inexplorado. Esta expedição, da qual participaram o astrônomo Rubtzov, o botânico Riedel e os pintores Taunay e Florans, durou seis anos, de 1822 a 1828. Colheu preciosas informações para o estudo das ciências naturais, assim como para a ciência etnográfica, no hinterland brasileiro. Esses materiais não foram publicados durante muito tempo e em parte continuam ignorados, porque o chefe da expedição, Langsdorf, adoeceu durante a viagem de uma doença psíquica e não pôde por em ordem e classificar as notas e as coleções recolhidas (3)".

\section{Conde EMMANUEL DE BENNIGSEN.}

(1). - Moscou, 1951. Editôra de Literatura Geográfica do Estado.

(2). - Ibidem, pág. 294, nota 70 .

(3). - Vide G. G. Manizer, A expedição do membro da Academia G. J. Langsdort ao Brasil, Geografgiz (Editôra geográfica do Estado), 1948; viđe também $N$. G. Slopintzin, Os indios spiaca (Os materiais da primeira expedição russa à América do Sul), Instituto de Etnografia da Academia das Ciências, Comuni: cados breves, 1950 .

G. G. Manizer tomou parte, em 1914-1915, numa expedição científica russa ao Brasil, da qual participaram também I. D. Strelnikov e outros cientistas. Manizer fêz mais tarde buscas no Instituto Etnográfico e, baseando-se em ma. nuscritos ali encontrados, cscreveu a biografia de Langsdorf e a descrição de sua viagem. As grandes coleções etnográficas de Langsdorf encontram-se agora nos museus da Academia de Ciências da Rússia. 